\title{
DIGITALIZATION OF HUMAN RESOURCE MANAGEMENT PRACTICES AND ITS IMPACT ON EMPLOYEES’ WELL-BEING
}

\author{
Alena FEDOROVA $\mathbb{D}^{1 *}$, Olga KOROPETS $\mathbb{D}^{2}$, Mauro GATTI(D) ${ }^{3}$ \\ ${ }^{1,2}$ Department of the Personnel Management and Psychology, Ural Federal University, \\ Mira Street, 620102, Yekaterinburg, Russian Federation \\ ${ }^{3}$ Department of the Management, Sapienza University of Rome, Del Castro Laurenciano Street, \\ 00161, Rome, Italy \\ *E-mail: a.e.fedorova@urfu.ru
}

\begin{abstract}
Purpose - the purpose of the article is assessing the impact of the processes of the labor activity digitalization on employees' well-being that have not yet received sufficient attention in HRM research and practice. The causal relationship between the digital transformation of the HRM practices and employees' well-being is examined in the paper.

Research methodology - the research methodology involves the analysis of data obtained by means of sociological surveys, narrative and content analysis. Additionally, the case study method allows us to explore the problem in detail using the example of the largest Russian university.

Findings - the results of our study identify the problematic issues resulting from expanding the practice of applying digital technologies in HRM system, proving the negative impact of digitalization processes on employee well-being (along with positive effects), and, therefore, the need to develop management solutions aimed at preserving well-being in the workplace.
\end{abstract}

Research limitations - the limitations of this pilot research are primarily due to the insufficient sample size that will be overcome in the future annual monitoring study.

Practical implications - searching for new management decisions and models aimed at prevention of worsening wellbeing at work in organizations that introduce digital technology.

Originality/Value - the novelty of this study consists in examining the HRM digitalization process in the context of social pollution of the labor sphere.

Keywords: digitalization, labor relations, human resource management, employees well-being, social pollution.

JEL Classification: J530, I310.

Conference topic: Digitalization of Business Processes: Trends, Challenges, Solutions.

\section{Introduction}

The digital business transformations (Westerman, Bonnet, \& McAfee, 2014) have led to the emergence of various trends in the field of human resource management (Volini, Stephan, Occean, \& Walsh, 2017). Having studied expert opinions we identified the following major trends:

- New models of HR management, whose application requires adapting business strategies to the conditions of a dynamic digital economy (Lengnick-Hall, Nelly, \& Stone, 2017). The success of companies (such as Apple, Disney, Google, Amazon, Nike, etc.), including their incredible market capitalization, to the PISA model, which involves ensuring effective performance in 4 areas: 1) Productivity: HR should measure and continuously increase labor productivity (i.e. income per employee), 2) Innovation: HR should encourage innovation, since it increases economic value 5 times more than productivity, 3) Speed: the first one gets more profit and income, which also motivates employees, 4) Adaptiveness: in an unstable world, constant adaptation and rapid scalability have significant value.

- Transformation of HR into a business partner and HR integration into the company's business processes, which is due to the requirement on the part of the business of equal rights and HR departments' responsibility for achieving financial and economic indicators. 
- The desire to achieve a perfect balance between employees' professional and personal life is the cornerstone of the worldview of generation $\mathrm{Y}$, which by 2020 will be ahead of generation $\mathrm{X}$ and will account for about $40 \%$ of the total labor force in developed countries (Berber, Dordevic, \& Milanovic, 2018).

- Fundamental changes in the field of labor management are associated with the transformation of traditional organizational structures: HR departments are supplemented by personnel development divisions responsible for talent, knowledge and involvement management, and digital units. The HRM team is strengthened by economists, analysts and IT professionals, who develop their professional competencies in the field of HRM.

- Active development and implementation of corporate mobile applications for working with staff in all areas: from recruiting to engagement management.

Deloitte experts identify three main areas of digital technology influence on HR management field: 1) digital workforce: introduction of new management methods, a culture of innovation and "sharing", a set of practical skills that contribute to the creation of a new network organization (White \& Grueger, 2017), 2) digital workspace: design of the working environment, use of modern communication tools (such as Slack, Workplace by Facebook, Microsoft Teams, etc.), 3) digital HR management: the use of digital tools and applications for delivering solutions, experimenting and introducing innovation (Stephan et al., 2016).

Digital technologies are used in various HR processes, most noticeably in such areas as working with large amounts of data (big data), computer-aided training, using artificial intelligence for personnel selection and evaluation, organizing employee feedback online and a number of other areas. A fundamentally new category of tools (intelligent systems) has emerged that can ensure an individual approach to developing leaders, evaluating candidates and finding the right people, recommending optimal training, identifying fraud attempts, developing stress in employees and other problems in the organization. Currently, software with elements of artificial intelligence is able to solve almost the full range of problems HR-managers face: from choosing a candidate to analyzing the emotional state of an employee (Berzinya, 2018). Such software can analyze the computer activity of a particular employee (e-mail, visited web pages, documents opened) and identify activities that reduce productivity, as well as assess the emotional state of employees based on their correspondence and messages in chat rooms.

Digital technologies inevitably make companies more "transparent": specialized online resources allow us to see salary levels, to find out the specifics of conducting interviews in certain companies, including possible questions, etc. Information about companies spreads quickly online and bad feedback from employees becomes public. The amount of feedback that a company receives from employees increases by 10 times on average when appropriate mobile HR applications are introduced. Barriers between work and personal life are destroyed: employees are available almost anytime and anywhere.

At the same time, the digitalization of economic activity is associated with the emergence of new labour risks and contradictions, among which the following should be mentioned: increased differentiation and flexibility of the labor market segments, the emergence of new forms of employment, types of labor relations (individualization of labor relations) and labor pricing methods (Kolosova, 2018a).

The following new employment forms have emerged (Mandl, 2017; Lucio \& MacKenzie, 2017), or have increased in importance since around 2000:

- employee sharing: an individual worker is jointly hired by a group of employers to meet their HR needs, resulting in permanent full-time employment for the employee;

-job sharing: an employer hires two or more employees to jointly fill a specific position, combining two or more part-time jobs into a full-time position;

-interim management: highly skilled experts are hired temporarily for a specific project or to solve a specific problem, thereby integrating external management capacities in the organization;

- casual work: an employer is not obliged to provide work regularly to the employee, but has the flexibility of calling them in on demand;

- ICT-based mobile work: workers can do their job from any place at any time, supported by modern technologies;

- voucher-based work: the employment relationship is based on payment for services with a voucher purchased from an authorized organization that covers both pay and social security contributions;

- portfolio work: a self-employed individual works for a large number of clients, doing small-scale jobs for each of them;

- crowd employment: an online platform matches employers and workers, often with larger tasks being split up and divided among a "virtual cloud" of workers;

- collaborative employment: freelancers, the self-employed or micro enterprises cooperate in some way to overcome limitations of size and professional isolation.

These wide-ranging new employment forms have an equally wide range of implications for working conditions and the labor market:

- employee sharing, job sharing, and interim management seem to offer beneficial working conditions, combining enhanced flexibility for workers with a good level of job security; 
-ICT-based mobile work offers some flexibility, autonomy, and empowerment, but also incurs the danger of work intensification, increased stress levels and working time, and blurring of the boundaries between work and private life. It may also outsource traditional employer responsibilities, such as health and safety protection, to workers;

- for freelancers and the self-employed, portfolio work, crowd employment and collaborative employment may enrich work content through diversification;

- voucher-based work entails some job insecurity, social and professional isolation, and limited access to HR measures and career development, but offers workers the opportunity to work legally, better social protection and perhaps better pay;

- casual work is characterized by low income, job insecurity, poor social protection and little or no access to HR benefits. The high level of flexibility might benefit some workers, but for most, it is too much and they would prefer more continuity.

Most of these employment forms contribute to labor market innovation and make it more attractive for both employers and a wider range of potential employees. However, there is a danger of labor market segmentation, particularly from casual work and voucher-based work, if the result is a widespread acceptance of fragmented jobs that are inherently linked to low income and limited social protection. ILO's "World Employment and Social Outlook - Trends 2016" report state that the global rate of precarious, unprotected employment is forecast to be $45.8 \%$ in 2019 , which does not take into account "digital preparation of employment".

In our previous studies, the phenomenon of social pollution from the economic activities of companies was identified, the essence of which is damaging welfare, as well as employees' physical and socio-psychological well-being (Fedorova et al., 2018). Among the main factors of social pollution, we distinguish precarious labor relations associated with a decrease in the level of social protection and precarious employment (Fedorova, Morokhov, Gerasimovich, \& Tyuyusheva, 2018). The growing trend of staff flexibility can be economically viable and profitable, but the cost is the failure to meet basic human needs - a sense of security and confidence in the future (Kulkova, Plutova, \& Tonkikh, 2018). The search for managerial solutions to reduce the negative effects of the economy digitization on the labor sphere is a pressing problem of the digital economy in the content of the New Labour Economy (Kolosova, 2018b). Systematic monitoring of the real processes of labor relations transformation will allow us to identify the emerging risks and contradictions that worsen the quality of the working life and, therefore, require new methods and tools to counteract.

\section{The introduction of digital HR-technologies in Russian organizations}

\subsection{Survey results}

Companies, using various tools, are at different levels of mastering digital technologies in the field of HR. While some are just beginning to introduce some HR technology, others are already abandoning it. The analysis of the digital technologies and products in the field of personnel management that are being implemented and are losing their relevance was conducted with the participation of the authors as respondents on the basis of data presented in the "Dying and Emerging HR Technologies" report conducted by the Talent Code group from March 20 to April 30, 2017. The study involved 159 Russian companies divided into 13 groups by industry: retail trade $-9.4 \%$, manufacturing $-8.8 \%$, banking and financial sector $-8.8 \%$, information technology $-8.8 \%$, transport and logistics $-5 \%$, power engineering $-4.4 \%$, metallurgy and mining industry $-3.8 \%$, telecommunications and communication $-3.1 \%$, real estate and construction $-3.1 \%$, oil, gas and chemical industry $-2.5 \%$, service industry $-2.5 \%$, hotel and restaurant business $-1.9 \%$, other industries $-38 \%$.

When analyzing the HR technologies implemented by participating companies, the prevalence of the use of digital technologies in various industries was identified (see Table 1).

Table 1. The use of digital HR-technologis in Russian companies-participants in the 2017 survey (source: authors)

\begin{tabular}{|c|c|c|c|c|c|c|c|c|c|c|c|c|c|}
\hline 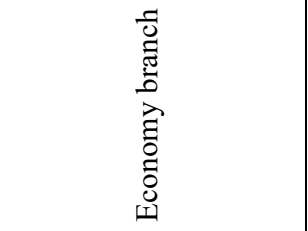 & 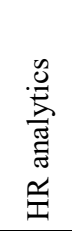 & 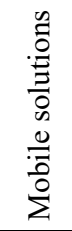 & 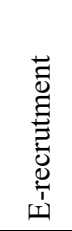 & 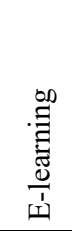 & 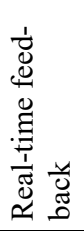 & $\begin{array}{l}0 \\
0 \\
0\end{array}$ & 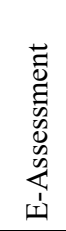 & 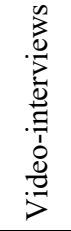 & $\frac{0}{\frac{80}{4}}$ & 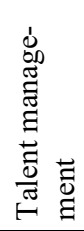 & 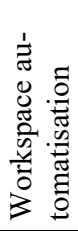 & 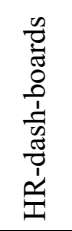 & $\frac{\overline{\vec{d}}}{\overline{0}}$ \\
\hline Retail & 6.7 & 33.3 & 6.7 & 20 & 13.3 & 13.3 & 20.0 & 13.3 & 0.0 & 0.0 & 0.0 & 0.0 & 6.7 \\
\hline Manufacturing & 14.3 & 7.1 & 21.4 & 7.1 & 0.0 & 0.0 & 0.0 & 7.1 & 7.1 & 0.0 & 21.4 & 0.0 & 7.1 \\
\hline Banking & 21.4 & 28.6 & 0.0 & 7.1 & 21.4 & 14.3 & 0.0 & 14.3 & 14.3 & 7.1 & 14.3 & 14.3 & 7.1 \\
\hline IT & 7.1 & 14.3 & 7.1 & 7.1 & 21.4 & 7.1 & 0.0 & 0.0 & 0.0 & 7.1 & 0.0 & 7.1 & 14.3 \\
\hline Transport and logistics & 42.9 & 14.3 & 28.6 & 42.9 & 0.0 & 14.3 & 14.3 & 0.0 & 0.0 & 14.3 & 0.0 & 0.0 & 0.0 \\
\hline
\end{tabular}




\begin{tabular}{|c|c|c|c|c|c|c|c|c|c|c|c|c|c|}
\hline 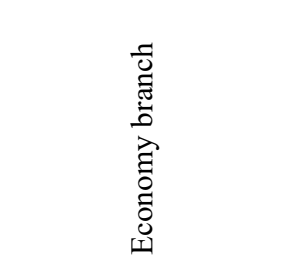 & 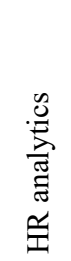 & 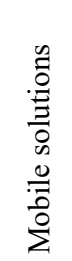 & 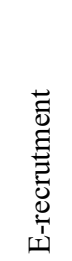 & & 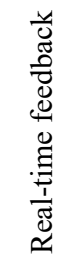 & $\stackrel{n}{0}$ & 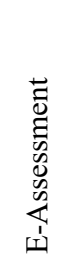 & 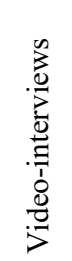 & $\frac{0}{\frac{50}{4}}$ & 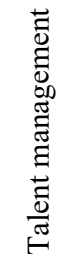 & 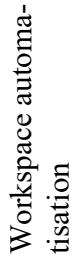 & 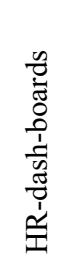 & $\frac{\dot{\Phi}}{\tilde{D}}$ \\
\hline Power-engineering & 42.9 & 0.0 & 0.0 & 14.3 & 14.3 & 28.6 & 14.3 & 0.0 & 28.6 & 0.0 & 0.0 & 0.0 & 14.3 \\
\hline Metallurgy & 33.3 & 33.3 & 16.7 & 0.0 & 0.0 & 16.7 & 16.7 & 0.0 & 0.0 & 0.0 & 0.0 & 0.0 & 33.3 \\
\hline Telecommunications & 40.0 & 20.0 & 20.0 & 0.0 & 20.0 & 40.0 & 0.0 & 0.0 & 20.0 & 0.0 & 0.0 & 0.0 & 40.0 \\
\hline Education & 0.0 & 0.0 & 0.0 & 0.0 & 0.0 & 0.0 & 20.0 & 0.0 & 0.0 & 40.0 & 0.0 & 0.0 & 20.0 \\
\hline $\begin{array}{l}\text { Oil, gas and chemical } \\
\text { industry }\end{array}$ & 66.7 & 33.3 & 0.0 & 33.3 & 0.0 & 0.0 & 0.0 & 0.0 & 0.0 & 0.0 & 0.0 & 0.0 & 0.0 \\
\hline Services & 7.5 & 2.5 & 15.0 & 10.0 & 5.0 & 2.5 & 2.5 & 10.0 & 5.0 & 2.5 & 0.0 & 0.0 & 10.0 \\
\hline Hotel and catering & 0.0 & 0.0 & 0.0 & 0.0 & 0.0 & 0.0 & 33.3 & 0.0 & 0.0 & 0.0 & 33.3 & 66.7 & 0.0 \\
\hline
\end{tabular}

Based on the data in the table, conclusions can be drawn about the prevalence of digital HR-technologies in various sectors of the surveyed enterprises: HR-analytics - in the oil, gas and chemical industries, transport and logistics, and power engineering; mobile solutions - in the metal and mining industries, oil, gas and chemical industries, retail; E-recruitment - in the field of transport and logistics, manufacturing, telecommunications and communications; E-learning - in the field of transport and logistics, oil, gas and chemical industries, retail trade; bots - in the field of telecommunications, power engineering; Real-time feedback - in the banking and financial sector, in the field of information technology; E-assessment - in the hotel and restaurant business; video interviews - in the banking and financial sector, retail; HR automation in general - in telecommunications, in the hotel and restaurant business; agile - in the field of power-engineering, telecommunications; talent management software - in education; workplace automation - in the hotel and restaurant business; HR dashboards - in the hotel and restaurant business.

In general, the introduction of such digital HR-technologies as workplace automation and HR-dashboards were noted only in companies in three industries. 12 (85.7\%) of the 14 digital HR technologies presented in the table are used in the banking and financial sector, as well as in the service sector. The least covered by digital HR technologies are oil and gas and chemical industries, as well as education.

While companies are introducing any HR technologies, they discard others that are outdated and have lost their relevance. Based on the report data, HR-technologies were identified which are abandoned by the largest number of companies. $15 \%$ of the surveyed companies abandon paper workflow, $5 \%$ of the companies also abandon manual calculations and reporting, including the use of Excel. As for the personnel assessment process, $5 \%$ of the total number of companies give up assessment centers, $3.1 \%$ stop using the 360 -degree assessment system, about $4 \%$ of companies no longer conduct staff performance appraisal, and $2.5 \%$ no longer use personal questionnaires for personnel evaluation. In the system of personal training and professional development, long-term training programmes $(3 \%$ of surveyed companies) and full-time studies ( $8 \%$ of surveyed companies) are rejected. About $4 \%$ of the companies surveyed prefer not to use in-person interviews when recruiting staff. The same number of companies do not use annual staff assessment in the process of performance management. Approximately $3 \%$ of the surveyed organizations are planning to abandon personnel records management.

\subsection{Case-study}

Ural Federal University named after the first President of Russia B.N. Yeltsin (Ural Federal University) is a federal university located in Yekaterinburg, Sverdlovsk region. The main activities of the institution include: 1) educational activities: educational programmes of higher education, secondary vocational education, basic general education programmes, basic vocational training programmes, additional general education programmes and additional professional programmes, 2) research activities, 3) organization of socially significant events in the field of education and science.

Currently, more than 35,000 students are enrolled in Ural Federal University, with about 2,000 foreign students from 80 countries of the world. The Ural Federal University staff of more than 6,600 people includes the following main categories: executive staff, teaching staff, researchers, engineering and technical staff, administrative personnel, production personnel, educational support staff, service staff.

The process of digitization of the personnel management system at UrFU is aimed at 1) creating effective internal communications, 2) automating the processes of information exchange and reporting, 3) reducing operating expenses, 4) increasing the efficiency of employees in areas such as technological effectiveness and flexibility of the educational process and organizing research activities. In general, the digitalization process is aimed at creating a "global online state", 
when all processes are performed online, all university activities are maximally reflected in information systems, and each user has barrier-free and convenient access to the information they need in accordance with their status or role.

The digitalization of the personnel management system in Ural Federal University is carried out using the information system "Staff Member's Personal Account", which is a single information space for university employees, providing access, depending on the position, to information resources and systems used by the university, including: corporate e-mail; electronic document management system; project management information system; incentive system for research and teaching staff; information systems and services accompanying educational activities; library services; IT services; scientific research services; services of various university structural units; services for heads of structural divisions - a system for analyzing and forecasting key indicators of the university based on IBM Cognos and others. The "Employee Profile" service was created for the faculty members to enter their personal information, with subsequent verification of the published information by a moderator and the publication of a personal page on UrFU official website. The service of publishing personal pages of research and teaching staff members is designed to automate this process in the form of open data. The service contains three sections: "Basic Information", "Personal Page" and "Education".

It should be noted that the university widely uses performance management services for the educational and research activities of the university's research and teaching staff (E-Assessment and E-Learning). The "My Indicators" service is used to evaluate the performance indicators: it includes the "Effective Contract" service and the "System of Incentives". These allow the university to track the actual performance of each employee according to incentive system indicators and automatically accrue incentive points. The service functions are: to support the processes of creation, editing, deletion, storage of indicators of the incentive system; automating the collection of actual values for incentive indicators; coordination of actual values in case of manual entry; providing research and teaching staff with consolidated reports; online scoring; the ability to build performance reports: by university, by institute, by department, by employee; integration with information systems. An effective contract essentially involves financial incentives for university employees, depending on their performance indicators, and is an element of the overall employee incentive system used in UrFU to motivate staff for improving performance. The "Effective Contract" service allows for the collection and recording of information on the effectiveness of educational and research activities and reaching performance indicators.

Educational and scientific services are a professional toolkit for the university's research and teaching staff; they are constantly improved, which requires the employees to develop relevant competencies. For example, the Pure information and analytical system are designed to manage UrFU research activities. The purpose of the Moodle e-Learning service is to provide access to electronic educational resources hosted in the online e-learning system at any time using a computer, tablet or a smartphone. The platform makes it possible to: develop, manage and distribute educational online materials, give joint access to them; organize the learning process; create materials in visual learning environment setting the required sequence, organize and carry out assessment; store materials safely using secure data transmission protocols, etc.

Thus, in general, it can be argued that the information system "Staff Member's Personal Account" is multi-functional and provides access to a large number of services that simplify and improve many processes that UrFU employees' professional activity involves. Due to the use of this digital technology, employees' time is saved, and their labor efficiency increases. Providing access to a large number of additional opportunities is one of the factors in increasing employees' loyalty to the university.

To assess the degree of satisfaction with the UrFU information system "Staff Member's Personal Account", a survey of university research and teaching staff was conducted in 2018. The questionnaire contained 15 mandatory questions and 1 space for additional comments. The survey was conducted via e-mail outs, answers were received from 250 respondents, which is $8.3 \%$ of the total number of research and teaching staff. According to the results of the survey, this information system was highly appreciated by the respondents: $40 \%$ rated the system "excellent" and $60 \%$ rated it as "good." Also, the respondents showed a high level of satisfaction with the convenience of using the account $(60 \%$ - "excellent" and $40 \%$ - "good"), the speed of accessing the necessary services and information ( $40 \%$ - "excellent", $40 \%$ - "good" and $20 \%$ - "satisfactory"), comfortable user-friendly interface ( $40 \%$ - "excellent", $60 \%$ - "good"), functionality (20\% - "excellent", $80 \%$ - "good") and usefulness (20\% - "Excellent", $80 \%$ - "good"). Nevertheless, it is obvious that this information system does not satisfy all the professional needs of university employees. In particular, the respondents would like to receive services such as an planner/personal calendar (40\%), a handbook with contacts of students in charge of their academic groups (60\%), a mobile application "Staff Member's Personal Account" with a set of essential functions $(20 \%)$, a forum for department staff $(40 \%)$, etc. "The lack of a university forum does not contribute to the active promotion of innovation and the university community bonding," the respondents declare. In addition, the respondents would like the system to include "Trade union news and interaction with the trade union".

Thus, it can be argued that employees want to see the information system "Staff Member's Personal Account" not only as a convenient tool for carrying out professional activities but also as a platform for meeting their social needs. It seems promising to digitize such university personnel management processes as recruitment and hiring, an adaptation of newly hired employees, talent management, personnel records and reporting. 


\section{Assessing the impact of HR-technologies' digitalization on employee well-being: a narrative analysis}

\subsection{Methods}

To study the impact of HRM digitalization on employee well-being, a narrative analysis of accounts by people working in different organizations that have introduced digital technologies was conducted. Narrative analysis, as a qualitative research method has certain advantages compared with quantitative methods, as it allows evaluating the subjective perception of HRM digitization by employees, highlighting the positive and negative effects of HR-technologies on physical and psychosocial well-being in the workplace. The difficulty of using the method of narrative analysis is due to the significant time spent on its implementation, associated with the audio recording of narratives and the subsequent decoding of data. Therefore, in order to obtain the relevant information, during the narrative interviews, the respondents were asked to write down their thoughts on the topic we set. When writing a narrative, a person, as a rule, cuts off all the unnecessary and focuses on the most important information regarding the described phenomenon. As a narrative impulse, we proposed the following phrase: "Please describe how information and communication/digital technologies affected your work and how their introduction in the organization could affect your future." The analysis of collected narratives was carried out through the integration of bottom-up and top-down approaches. In interpreting the data, we relied on some of the questions proposed by Linde (2000), given that the reason for the account was the request of the researcher: 1) who tells the story, 2) what main events characterize the story, 3) what the narrator's assessment is.

Based on the analysis of the scientific literature on this issue (Bruner, 1987; Clandinin \& Connelly, 2000; Jovchelovitch \& Bauer, 2000; Etherington \& Bridges, 2011; Fehér, 2011; Muylaert et al., 2014; Iş1k, 2015) we identified three main thematic cores for interpreting the results:

- General evaluation of digitization in the field of labor and labor relations;

- Possible concerns related to the introduction of information and communication/digital technologies in the organization of labor;

- Reflections on the possibilities of improving the introduction of information and communication/digital technologies in the organization of labor.

We conducted narrative interviews and studied written accounts of 57 respondents, 35 women and 22 men, aged from 22 to 41, working in various sectors of the economy, including education, health care, personal services, management and finance, commerce, construction, social sphere, IT and communications, civil service.

\subsection{Results}

The following results were obtained on the thematic core "General Evaluation of Digitalization in the Sphere of Labour and Labour Relations" (Table 2). More than half of the respondents (59.6\%) distinguish both positive and negative aspects when evaluating the introduction of digital technologies in their activities, and $40.3 \%$ respondents associate the digitalization of their activities with positive aspects exclusively. The positive aspects of digitalization pointed out by the respondents are: facilitating the production process, speeding up work, saving time, increasing the speed of communication with colleagues and clients, the possibility of remote employment, the possibility of storing large amounts of data, minimizing the influence of the human factor, etc. The negative aspects are health problems associated with working on a computer, visual impairment, physical inactivity, and even computer addiction.

Table 2. An example of narrative analysis by thematic core "General evaluation of digitization in the labor sphere" (source: authors)

\begin{tabular}{|l|l|l|}
\hline Evaluation & \multicolumn{1}{|c|}{ Keywords } & \multicolumn{1}{c|}{ Quotes } \\
\hline Positive & $\begin{array}{l}\text { the convenience of work, } \\
\text { saving time, } \\
\text { fast communication, } \\
\text { inevitability, } \\
\text { technology, } \\
\text { increased profits, } \\
\text { the need for digitalization, } \\
\text { distance learning, } \\
\text { development, } \\
\text { minimization of the hu- } \\
\text { man factor }\end{array}$ & $\begin{array}{l}\text { "Digital technology is everywhere, we cannot do without it." } \\
\text { "The introduction of digital technology increases the company's profits." } \\
\text { "Keeping records electronically significantly reduces the time spent searching for } \\
\text { information." } \\
\text { "Digitalization has had a positive effect on my life: I learned a lot of things, I } \\
\text { work with dozens of cleverest programs." } \\
\text { "The importance of distance learning is worth noting. People with disabilities } \\
\text { have a chance to get an education and developmentally." }\end{array}$ \\
\end{tabular}


End of Table 2

\begin{tabular}{|l|l|l|}
\hline \multicolumn{1}{|c|}{ Evaluation } & \multicolumn{1}{|c|}{ Keywords } & \multicolumn{1}{c|}{ Quotes } \\
\hline $\begin{array}{l}\text { Both posi- } \\
\text { tive and } \\
\text { negative as- } \\
\text { pects are } \\
\text { identified }\end{array}$ & $\begin{array}{l}\text { labor facilitation, } \\
\text { acceleration of work, } \\
\text { saving time, } \\
\text { convenience, } \\
\text { deterioration of health, } \\
\text { deterioration of vision, } \\
\text { hypo dynamic, } \\
\text { osteochondrosis, } \\
\text { remote employment, } \\
\text { computer addiction }\end{array}$ & $\begin{array}{l}\text { "I believe that the social transition to new technologies and to new information } \\
\text { systems is positive, as it speeds up the work processes, and makes work easier } \\
\text { and saves time. The downside is the negative impact on human health." } \\
\text { "Convenience and reduction of working time, but a large amount of working } \\
\text { time is spent at the computer, which leads to loss of vision and physical inactiv- } \\
\text { ity." } \\
\text { "The advantages are quick to access to information, the ability to communicate at } \\
\text { a distance, developing logical thinking, reduced risk of error. But my eyesight } \\
\text { and posture deteriorated, my interest in personal development was lost, I became } \\
\text { dependent on PC." } \\
\text { "On the one hand, the working chat is convenient to communicate with col- } \\
\text { leagues; on the other hand, to be always connected is stressful". }\end{array}$ \\
\hline
\end{tabular}

According to the thematic core "Possible concerns related to the introduction of information and communication/digital technologies in the organization of labor," the following data were obtained. Most of the respondents (86\%) are afraid of work stoppages associated with an unexpected power outage and "freezing" of computer software; $52.6 \%$ of the respondents fear that older people will remain without work due to difficulties in mastering new technologies; $17.5 \%$ of the respondents point out the high cost of new technologies and low-quality software they use. The risk of unemployment due to robotization worries $21 \%$ of the respondents; $14 \%$ indicated possible risks due to the loss of databases. There were also individual concerns related to the degradation of thinking ("a computer will think for us and our thinking will degrade"), a negative influence on the ability to express our thoughts in a grammatically and syntactically accurate way, as well as fears of a decrease in "humanity" in the social sphere (see Table 3 ).

Table 3. An example of narrative analysis by thematic core "Possible concerns related to the introduction of information and communication/digital technologies in the organization of labor" (source: authors)

\begin{tabular}{|c|c|c|}
\hline Concern & Keywords & Quotes \\
\hline $\begin{array}{l}\text { Technology } \\
\text { malfunctions }\end{array}$ & $\begin{array}{l}\text { electric power, } \\
\text { program glitches, } \\
\text { technical errors, } \\
\text { freezing, } \\
\text { impossible to work }\end{array}$ & $\begin{array}{l}\text { "I work as a teacher. The equipment may fail at any time, the computer may } \\
\text { glitch, a power failure may occur, an animation will not work due to the differ- } \\
\text { ence in office software. Therefore, it's not a fact that the classic board is not } \\
\text { useful." } \\
\text { "One has only to turn off electricity, and all the work in our office is para- } \\
\text { lyzed." }\end{array}$ \\
\hline $\begin{array}{l}\text { Inadequate } \\
\text { equipment } \\
\text { quality }\end{array}$ & $\begin{array}{l}\text { cost, } \\
\text { price, } \\
\text { small budget } \\
\text { software quality, } \\
\text { high-quality equipment }\end{array}$ & $\begin{array}{l}\text { "The quality of the equipment is not always adequate; our organization cannot } \\
\text { afford expensive equipment and high-quality software." } \\
\text { "Unfortunately, for full labor digitization, there are not enough quality pro- } \\
\text { grams. Those available work slowly and freeze." }\end{array}$ \\
\hline $\begin{array}{l}\text { Difficulties } \\
\text { in mastering } \\
\text { digital tech- } \\
\text { nology older } \\
\text { people face }\end{array}$ & $\begin{array}{l}\text { retirement age } \\
\text { difficulties of mastering } \\
\text { skills, } \\
\text { elderly people, } \\
\text { pensioners' adaptation, } \\
\text { adult generation }\end{array}$ & $\begin{array}{l}\text { "Older people will find it harder and harder to get a job because they have little } \\
\text { in terms of digital skills." } \\
\text { "The adult generation does not keep up with the technologies (taking into ac- } \\
\text { count the increase in the retirement age, it is difficult to adapt)." }\end{array}$ \\
\hline $\begin{array}{l}\text { Unemploy- } \\
\text { ment due to } \\
\text { the disap- } \\
\text { pearance of } \\
\text { jobs }\end{array}$ & $\begin{array}{l}\text { job loss } \\
\text { robotization, } \\
\text { the disappearance of pro- } \\
\text { fessions } \\
\text { unemployment }\end{array}$ & $\begin{array}{l}\text { "Robotization threatens the disappearance of a number of recruitment func- } \\
\text { tions." } \\
\text { "I am afraid that a number of professions will disappear due to robotization and } \\
\text { digitalization, and I will have no place to work." }\end{array}$ \\
\hline $\begin{array}{l}\text { Database } \\
\text { loss risk }\end{array}$ & $\begin{array}{l}\text { hackers, } \\
\text { data loss, } \\
\text { data theft } \\
\text { personal information }\end{array}$ & $\begin{array}{l}\text { "In our work, there is always the risk of data hacking, theft of copyright tech- } \\
\text { nologies." } \\
\text { "Once, an employee in our office, when he was dismissed, copied the client } \\
\text { base for his personal use, and it was not possible to prove anything." }\end{array}$ \\
\hline
\end{tabular}


The thematic core "Reflection on the possibilities of improving the introduction of information and communication/digital technologies in the organization of labor", in contrast to the cores described above, was represented in $8.8 \%$ of the respondents' narratives. This may be due to the fact that the majority of the respondents do not fully understand future digital technologies, and disclaim responsibility for their distribution and improvement or their participation in this process. The resulting statements are connected with mastering new skills and restructuring thinking, with certain personal qualities necessary to adapt to changes, with the search for a golden mean between digitalization and traditional methods of work, as well as with the conviction that "live" human communication will never replace a computer or robot (see Table 4). An interesting fact is that none of the participants indicated the need to introduce health-saving technologies aimed at overcoming the negative effects of digitalization, despite the fact that poor health is one of the main negative consequences of digitalization, according to the respondents.

Table 4. An example of narrative analysis by thematic core "Reflection on the possibilities of improving the implementation of information and communication ldigital technologies in the organization of labor" (source: authors)

\begin{tabular}{|c|c|c|}
\hline Concern & Keywords & Quotes \\
\hline Mastering new skills & $\begin{array}{l}\text { learning, training, } \\
\text { skills, } \\
\text { changes, } \\
\text { ability to learn }\end{array}$ & $\begin{array}{l}\text { "If a person has change management skills, then they will be a suc- } \\
\text { cess." }\end{array}$ \\
\hline $\begin{array}{l}\text { Restructuring thinking } \\
\text { and adaptability }\end{array}$ & $\begin{array}{l}\text { restructuring thinking, } \\
\text { adaptation, adaptability, } \\
\text { "new" people, } \\
\text { the new way of life, } \\
\text { new working conditions }\end{array}$ & $\begin{array}{l}\text { "We all, most likely, will have to learn to live in the world of ro- } \\
\text { bots, smart machines, which will require a tremendous restructur- } \\
\text { ing of thinking, business approaches and lifestyle from a large } \\
\text { mass of people." } \\
\text { "We need to learn to adapt to rapidly changing working condi- } \\
\text { tions." }\end{array}$ \\
\hline $\begin{array}{l}\text { The advantage of a "liv- } \\
\text { ing" person }\end{array}$ & $\begin{array}{l}\text { creativity, } \\
\text { humanity, } \\
\text { soul, } \\
\text { heartfulness, } \\
\text { "live" communication, } \\
\text { inner world, } \\
\text { feelings, } \\
\text { emotions }\end{array}$ & $\begin{array}{l}\text { "I am convinced that one of the main advantages of a living person } \\
\text { compared to an electronic copy is creativity, the ability to find an } \\
\text { individual approach to employees and the ability to act in unusual } \\
\text { situations, because we are engineers of human souls who can feel } \\
\text { the inner world of the applicant, which no gadget in the world can } \\
\text { do." }\end{array}$ \\
\hline $\begin{array}{l}\text { Finding the golden mean } \\
\text { between digitalization and } \\
\text { traditional labor methods }\end{array}$ & $\begin{array}{l}\text { balance, } \\
\text { the golden mean, } \\
\text { new technologies, } \\
\text { traditional methods, } \\
\text { off-line and online commu- } \\
\text { nication }\end{array}$ & $\begin{array}{l}\text { "It is necessary to find a balance between new technologies and } \\
\text { traditional methods." } \\
\text { "You can not trust all the mathematical calculations to the pro- } \\
\text { gram, sometimes you need to calculate by yourself." }\end{array}$ \\
\hline
\end{tabular}

Thus, the results of the narrative analysis allow us to draw the following conclusions. The overwhelming majorities of the respondents are positive about the introduction of digital technologies in the organizations' activities and believe that progress cannot and should not be stopped. The negative aspects of the introduction of digital technologies are related, according to the respondents, to their imperfections and high cost, as well as to the negative impact on the health of employees. Possible concerns are associated with the insufficient reliability of technology and difficulties in mastering new technologies that older people face. The respondents in the sample are less concerned about improving the introduction of information and communication/digital technologies in work organization but note the need to adapt to the rapidly changing working conditions.

\section{Conclusions}

Digital technologies strongly influence the company's business strategy and the business model and are being perceived by many as a real threat for human employees' work and jobs. Companies concerned with the digital transformation of the business sphere should align their strategic vision and mission to the philosophy of HRM. All HR processes are affected by digital technologies, as they represent promising tools for enhancing HRM effectiveness and efficiency. But, in order to cope with a much more complex environment and competition, the extensive adoption of digital technologies must fit with the organizational culture and the company's core values, and be supported by a proper combination of HRM practices. The integration of digital technologies into HR policies and practices must 
bring benefits to the overall employee well-being and must be evaluated not only in terms of their effectiveness and efficiency but also in terms of perceived equity and fairness by all employees.

Digital technologies are drastically modifying the way employees respond to different stimuli and signals. They are influencing: cognitive processes (perception (what stimuli/signals people pay attention to and how people receive stimuli), elaboration, and interpretation), mindset structure (attitudes, motivations, emotions, intentions, preferences, stereotypes), and responses (behaviors, interactions, learning).

This, in turn, impacts performance (productivity, absenteeism, turnover, citizenship, innovation, etc.), individual satisfaction (well-being, work-life balance) (Joyce et al., 2018), and organizational climate. The need, therefore, arises to consider the employees' potential responses to new incentives. Every work arrangement and /or modification must be accompanied by appropriate internal communication, to avoid withdrawal behaviors (e.g. disengagement) and low job performance. Managers are therefore required to take into account their employees' needs, to identify their level of stress and burnout.

The increasing prevalence of digital technologies influences the way people approach their work. A new digital workforce is developing. The digital workforce can be divided into two categories (Prensky, 2001): 1) digital natives: those that cannot remember the first time they accessed the Internet, and 2) digital immigrants: adults who have readily adopted technology as it has been available. The increased use of digital technologies has influenced competencies, self-awareness, and relational expectations of the digital workforce.

The study presented in the article reflects the results obtained in the course of a sociological survey and narrative interviews of respondents belonging to the category of digital immigrants. This category is currently the most vulnerable, most acutely perceiving all the difficulties of the transformation process, forced to constantly adapt to changes in the labor sphere occurring at a high speed. The limitations of this stage of the study are primarily due to the insufficient sample size, which does not allow for the identification of age, gender and other similarities and differences in the perception by employees of the processes of digitalization of labor and labor relations. In future studies, we plan not only to increase the number of respondents but also to develop a psycho-diagnostic method for assessing the extent to which social contamination affects the employees' physical and psychosocial well-being. Our research is aimed at long-term monitoring of changes in the labor sphere that lead to worsening employee well-being and working life quality, which requires searching for new management decisions and developing new management models in organizations that introduce digital technology.

\section{Funding}

This work was supported by Act 211 Government of the Russian Federation, contract № 02.A03.21.0006; Russian Foundation for Basic Research (RFBR) under Grant № 19-010-00705 "Development of tools for assessing the impact of social pollution of labor relations on the employees' well-being in a digital economy".

\section{Disclosure statement}

We declare that we do not have any competing financial, professional, or personal interests from other parties.

\section{References}

Berber, N., Dordevic, B., \& Milanovic, S. (2018). electronic human resource management (e-hrm): new concept for the digital age. Strategic Management, 23(2), 22-32. https://doi.org/10.5937/StraMan1802022B

Berzinya, A. (2018). Artificial Intelligence in human resources: key innovation trends. Retrieved from https://bigdatamadesimple.com/artificial-intelligence-in-human-resources-key-innovation-trends/

Bruner, J. (1987). Life as narrative. Social Research, 54(1), 691-712.

Clandinin, D. J., \& Connelly, F. M. (2000). Narrative inquiry experience and story in qualitative research. San Francisco: JosseyBass.

Deloitte. (2016). The digital workplace: using a distinctive, digitally enabled employee experience to drive value in mergers, acquisitions, and divestitures. Retrieved from https://www2.deloitte.com/content/dam/Deloitte/us/Documents/humancapital/us-cons-digital-workplace-in-mergers-acquisitions-connectme.pdf

Etherington, K., \& Bridges, N. (2011). Narrative case study research: on endings and six-session reviews. Counseling and Psychotherapy Research, 11(1), 11-22. https://doi.org/10.1080/14733145.2011.546072

Eurofound. (2016). New forms of employment: Developing the potential of strategic employee sharing. Publications Office of the European Union, Luxembourg. Retrieved from https://digitalcommons.ilr.cornell.edu/cgi/viewcontent.cgi?referer=https://www.google.com/\&httpsredir=1\&article=1602\&c ontext=intl

Fedorova, A., Dvorakova, Z., Kacane, I., Khna, H., Menshikova, M., \& Solek-Borowska, C. (2018). Toxic labor relations: the narrative case study. Paper presented at the ic-SIRS 2018 - 5th International Conference on Political Science, International Relations and Sociology. Olomouc, Czech Republic. https://doi.org/10.15405/epsbs.2018.03.02.6 
Fedorova, A., Morokhov, N., Gerasimovich, M., \& Tyuyusheva, Y. (2018). Influence of the employment precarization on the working life quality of Russian workers. Paper presented at the INTCESS 2018 - 5th International Conference on Education and Social Science. Istanbul, Turkey.

Fehér, B. (2011). Understanding the homeless experience in Hungary through a narrative approach. European Journal of Homelessness, 5(1), 49-65.

Iş1k, N. E. (2015). The role of narrative methods in sociology: stories as a powerful tool to understand individual and society. Journal of Sociological Research, 18(1), 103-125.

Jovchelovitch, S., \& Bauer, M. W. (2000). Narrative interviewing. London: LSE Research Online. Retrieved from http://eprints.lse.ac.uk/2633

Joyce, C., Guszcza, J., Fisher, J., \& Hogan, S. K. (2018). Designing work environments for digital well-being. Deloitte Insights. Retrieved from https:/www2.deloitte.com/insights/us/en/focus/behavioral-economics/negative-impact-technologybusiness.html

Kolosova, R. P. (2018a). Socio-labor relations in digital economy. Retrieved from https://www.econ.msu.ru/sys/raw.php? $\mathrm{o}=48746 \& \mathrm{p}=\mathrm{attachment}$

Kolosova, R. P. (2018b). The social context of economic development in the XXI century. Mirovaya Ekonomika I mezhdunarodnye otnosheniya, 62(1), 114-119.

Kulkova, I., Plutova, M., \& Tonkikh, N. (2018). The female students' attitude towards telecommuting and its coherence with fertility. Paper presented at the 12th International Days of Statistics and Economics. Prague, Czech Republic.

Lengnick-Hall, M. L., Neely, A. R., \& Stone, C. B. (2017). Human resource management in the Digital Age: big data, HR analytics and artificial intelligence. In P. N. Melo \& C. Machado (Eds.), Management and technological challenges in the digital age (pp. 1-30). Boca Raton: CRC Press.

Linde, C. (1993). Life stories: the creation of coherence. New York: Oxford University Press.

Lucio, M. M., \& MacKenzie, R. (2017). The state and the regulation of work and employment: theoretical contributions, forgotten lessons and new forms of engagement. International Journal of Human Resource Management, 28(21), 2983-3002. https://doi.org/10.1080/09585192.2017.1363796

Mandl, I. (2017). Examining emerging new employment forms and potential positive and negative effects on working and employment conditions. Administration, 65(4), 11-20. https://doi.org/10.1515/admin-2017-0030

Muylaert C. J., Sarubbi, J. V., Gallo, P. R., Neto, M. L. N., \& Reis, A. O. A. (2014). Narrative interviews: an important resource in qualitative research. Revista da Escola de Enfermagem da USP, 48(2), 184-189. https://doi.org/10.1590/S0080623420140000800027

Prensky, M. (2001). Digital natives, digital immigrants. On the Horizon. MCB University Press. Retrieved from http://www.marcprensky.com/writing/Prensky\%20-\%20Digital\%20Natives,\%20Digital\%20Immigrants\% 20-\%20Part1.pdf

Stephan, M., Uzawa, S., Volini, E., Walsh, B., \& Yoshida, R. (2016). Digital HR. Revolution, not evolution. Deloitte Insights. Retrieved from https:/www2.deloitte.com/insights/us/en/focus/human-capital-trends/2016/digital-hr-technology-for-hrteams-services.html

Volini, E., Stephan, M., Occean, P., \& Walsh, B. (2017). Digital HR: platforms, people, and work. 2017 global human capital trends. Retrieved from https://dupress.deloitte.com/dup-us-en/focus/human-capital-trends/2017/digital-transformation-inhr.html

Westerman, G., Bonnet, D., \& McAfee, A. (2014). The nine elements of digital transformation. Retrieved from http://sloanreview.mit.edu / article / the-nineelements-of-digital-transformation

White, N., \& Grueger, D. (2017). Managing the digital workforce. Retrieved from https://www2.deloitte.com/content/dam/Deloitt e/au/Documents/human-capital/deloitte-au-hc-managing-digital-workforce-131017.pdf 